\title{
Effects of Rupatadine on Platelet- Activating Factor-Induced Human Mast Cell Degranulation Compared With Desloratadine and Levocetirizine (The MASPAF Study)
}

\author{
Munoz-Cano R, ${ }^{1,2}$, Ainsua-Enrich $\mathrm{E}^{3}$, Torres-Atencio I', Martin $\mathrm{M}^{3}$, \\ Sánchez-Lopez J1,2, Bartra J1,2, Picado $\mathrm{C}^{1,2,5}$, Mullol J2,5,6* Valero $\mathrm{A}^{1,2,5 *}$
}

'Unitat d'Al-lèrgia, Servei de Pneumologia i Al-lèrgia Respiratòria, Hospital Clínic and Universitat de Barcelona, Barcelona, Catalonia, Spain

${ }^{2}$ Immunoal-lèrgia Respiratòria Clínica i Experimental, Institut d'Investigacions Biomèdiques August Pi i Sunyer (IDIBAPS), Barcelona, Catalonia, Spain

${ }^{3}$ Biochemistry Unit, School of Medicine, Universitat de Barcelona, Barcelona, Catalonia, Spain

${ }^{4}$ Pharmacology Department, School of Medicine, Universidad de Panamá, Panamá

${ }^{5}$ Centro de Investigaciones Biomédicas en Red de Enfermedades Respiratorias (CIBERES), Barcelona, Catalonia, Spain

${ }^{6}$ Unitat de Rinologia i Clínica de I'Olfacte, Servei d'Oto-rino-laringologia, Hospital Clínic and Universitat de

Barcelona, Barcelona, Catalonia, Spain

*Both authors had similar senior responsibilities

J Investig Allergol Clin Immunol 2017; Vol. 27(3): 161-168

doi: 10.18176/jiaci.0117

\footnotetext{
Abstract

Background: Platelet-activating factor (PAF) is a lipid mediator involved in the pathophysiology of several allergic diseases, for example, in the amplification of mast cell (MC) activation in anaphylaxis. Rupatadine is an antihistamine with a demonstrated anti-PAF effect, although its capacity to inhibit PAF-induced MC degranulation has not been fully evaluated.

Objectives: To compare the ability of rupatadine to inhibit PAF-induced MC degranulation with that of desloratadine and levocetirizine and to confirm the dual anti-H1 and anti-PAF activity of rupatadine.

Methods: The human MC line LAD2 and primary MCs (human lung tissue MCs [hLMCs]) were used. MC mediator release was evaluated using the $\beta$-hexosaminidase and histamine release assay. The effects of rupatadine ( $\mathrm{H} 1$ antagonist + PAF receptor antagonist), desloratadine, and levocetirizine (H1 antagonists) on LAD2 and hLMCs were compared. The PAF receptor antagonists WEB2086, BN52021, and CV6209 were also tested. PAF receptor protein expression was evaluated in both LAD2 and hLMCs.

Results: CV6209 and rupatadine inhibited PAF-induced MC degranulation in both LAD2 and hLMCs. In LAD2, rupatadine (5 and $10 \mu \mathrm{M})$ and levocetirizine $(5 \mu \mathrm{M})$, but not desloratadine, inhibited PAF-induced $\beta$-hexosaminidase release. Rupatadine (1-10 $\mu \mathrm{M})$, levocetirizine $(1-10 \mu \mathrm{M})$, and desloratadine $(10 \mu \mathrm{M})$ inhibited PAF-induced histamine release. Rupatadine at $10 \mu \mathrm{M}$ had an inhibitory effect on hLMC degranulation, but levocetirizine and desloratadine did not.

Conclusions: This study shows that rupatadine and, to a lesser extent, levocetirizine, but not desloratadine, inhibit PAF-induced degranulation in both LAD2 and hLMCs. These findings support the dual antihistamine and anti-PAF effect of rupatadine in allergic disorders.

Key words: CV6209. Desloratadine. LAD2. Levocetirizine. Mast cell. Platelet-activating factor. Rupatadine.
} 


\section{Resumen}

Introducción: El factor de activación plaquetario (PAF) es un mediador lipídico que ha sido involucrado en la fisiopatología de diversas enfermedades alérgica, como la amplificación de la activación de los mastocitos (MC) en la anafilaxia. Rupatadina es un antihistamínico que ha demostrado también un efecto anti-PAF, pero no ha sido elucidada su capacidad para inhibir la degranulación mastocitaria inducida por PAF.

Objetivo: Evaluar la capacidad de rupatadina para inhibir la degranulación de los MC inducida por PAF en comparación con desloratadina y levocetirizina, con el objetivo de confirmar el efecto dual anti-H1 y anti-PAF de rupatadina.

Métodos: Para este estudio se utilizaron la línea celular de mastocitos humanos LAD2 y mastocitos primarios (mastocitos pulmonares (MP)). Los mediadores mastocitarios se midieron utilizando las pruebas de liberación de $\beta$-hexosaminidasa e histamina. Los efectos de rupatadina (antagonista H1 + antagonista del receptor del PAF), desloratadina y levocetirizina (antagonista H1) se compararon en LAD2 y MP. También se probaron los antagonistas selectivos del receptor del PAF WEB2086, BN52021, y CV6209. La expresión proteica del receptor del PAF fue evaluada tanto en LAD2 como en MP.

Resultados: La expresión del receptor del PAF fue confirmada en LAD2 y MP. De los inhibidores anti-PAF, CV6209 y rupatadina inhibieron la degranulación mastocitaria inducida por PAF, tanto en LAD2 como en MP. En LAD2, rupatadina (5 y $10 \mu \mathrm{M})$ y levocetirizina (5 $\mu \mathrm{M})$, pero no desloratadina, inhibieron la liberación de $\beta$-hexosaminidasa inducida por PAF. Rupatadina (1 -10 $\mu \mathrm{M})$, levocetirizina (1-10 $\mu \mathrm{M})$, y desloratadina $(10 \mu \mathrm{M})$ inhibieron la liberación de histamina inducida por PAF. Rupatadina a $10 \mu \mathrm{M}$, pero ni levocetirizina ni desloratadina, demostraron efecto inhibitorio alguno sobre la degranulación inducida en MP.

Conclusiones: Este estudio demuestra que rupatadina, y en menor medida levocetirizina, pero no desloratadina, es capaz de inhibir la degranulación inducida por PAF en LAD2 y mastocitos pulmonares. Estos hallazgos apoyan el efecto dual anti-H1 y anti-PAF de rupatadina para su uso en las enfermedades alérgicas.

Palabras clave: CV6209. Desloratadina. LAD2. Levocetiricina. Mastocito. Factor activador de plaquetas. Rupatadina.

\section{Introduction}

Platelet-activating factor (PAF) is a lipid mediator released by many cells, including mast cells and eosinophils [1], which are implicated in allergic diseases such as asthma, allergic rhinitis, and anaphylaxis [2-4]. There is evidence that PAF can activate human lung mast cells (hLMCs), but not skin mast cells, through PAF receptor and phospholipase C- $\gamma 1$ and $-\beta 2$ [5]. These findings provide a plausible mechanism whereby PAF mediates an amplification loop for mast cell activation in the generation of the allergic response.

The role of PAF in asthma has been well established, and several studies have demonstrated that it is associated with bronchoconstriction and bronchial hyperreactivity [6,7]. Furthermore, PAF has been considered the most potent inducer of vascular permeability among the mediators involved in nasal inflammation, with a key role in rhinorrhea and nasal congestion [3,8-11]. Finally, PAF levels and, more interestingly, PAF acetylhydrolase activity have been related to the severity of anaphylaxis $[4,12]$.

PAF receptor expression has been described in human mast cells. PAF receptor has also been found in hLMCs, but not in skin mast cells [5]. No studies have been performed to date on the human mast cell line LAD2. PAF-induced mast cell degranulation is partially dependent on extracellular calcium, as demonstrated in human peripheral blood-derived mast cells [5] and in the human leukemia mast cell line HMC-1 [13].

Despite the significant relevance of PAF in the pathophysiology of allergic diseases, studies of PAF antagonists to date have failed to show a definitive and positive effect on bronchial symptoms [2,14]. Moreover, there are no studies with selective PAF antagonists in human rhinitis or anaphylaxis. Lack of evidence of the clinical efficacy of PAF antagonists probably accounts for their absence in the current armamentarium of allergic airway disease and the restriction of their use to research.

Rupatadine is an $\mathrm{H} 1$ receptor antagonist indicated for the treatment of allergic rhinitis [15] and urticaria [16]. It has the properties of an ideal second-generation antihistamine, including antiallergic/antiinflammatory effects such as inhibition of cytokine secretion $[8,17]$. In addition, the antagonistic effect of rupatadine on the PAF receptor has been demonstrated in in vitro studies and in a wide series of in vivo pharmacological studies based on both animals and humans [18]. The clinical anti-PAF effect of rupatadine was recently demonstrated using an in vivo human nasal provocation test with PAF $[9,10]$. However, the mechanism of action of the anti-PAF effect of rupatadine has not been fully evaluated in human mast cells $[17,19]$.

The objective of the MASPAF study was to investigate the ability of rupatadine to inhibit PAF-induced mast cell degranulation. To confirm its anti-H1 and anti-PAF dual effect, rupatadine was compared with selective anti-PAF antagonists and second-generation antihistamines (desloratadine and levocetirizine) with unknown PAF antagonist activity.

\section{Material and Methods}

\section{Reagents}

PAF, desloratadine, WEB2086, and BN52021 were purchased from Sigma-Aldrich. CV6209 was purchased from Enzo Life Sciences. Rupatadine and levocetirizine were provided by Grupo Uriach SA. 


\section{Mast Cell Cultures}

Mast cell line. The LAD2 human mast cell line, which was provided by A Kirshenbaum and DD Metcalfe (National Institutes of Health), was grown in StemPro-34 serum-free medium (Invitrogen Life Technologies), supplemented with StemPro-34 Nutrient and with L-glutamine $(2 \mathrm{mM})$, penicillin $(100 \mathrm{U} / \mathrm{mL})$, streptomycin $(100 \mathrm{mg} / \mathrm{mL})$, and $100 \mathrm{ng} / \mathrm{mL}$ recombinant stem cell factor (Preprotech) [10]. Cultures were stored at $37^{\circ} \mathrm{C}$ in $5 \% \mathrm{CO}_{2}$ in a humidified incubator.

Primary human lung mast cells. Healthy lung fragments confirmed by histopathology examination and obtained during elective surgery were selected. hLMCs were dispersed from chopped lung specimens by means of an enzymatic procedure and purified using a magnetic bead-based affinity selection method with anti-CD117 antibody (MiltenyBiotec) as described elsewhere [20]. Mast cell purity, which was assessed by metachromatic staining, was greater than $98 \%$. Cells were cultured in Dulbecco's Modified Eagle Medium (DMEM) (LifeTechnologies) supplemented with FBS 10\%, $100 \mathrm{ng} / \mathrm{mL}$ recombinant stem cell factor, IL-10 (1 ng/mL), and IL-6 $(0.5 \mathrm{ng} / \mathrm{mL})$ (Preprotech) for up to 5 days.

\section{Study Design}

Most of the experiments were performed in LAD2 owing to the limited availability of hLMCs. Desloratadine and levocetirizine, neither of which has a demonstrated anti-PAF effect, have been used to evaluate the differential anti-PAF effects of rupatadine. Conversely, CV6209, WEB2086, and BN52021 are PAF antagonists with a demonstrated inhibitory effect $[5,21,22]$.

Mast cell degranulation was evaluated using both $\beta$-hexosaminidase and histamine assays in LAD2 cells. First, time-course and dose-response assays were performed in order to determine the optimal dose and incubation time. PAF was tested at $1 \mu \mathrm{M}$ for 15 and 30 minutes and at $10 \mu \mathrm{M}$ for 5,15 , and 30 minutes. Second, mast cells were preincubated with antihistamines or anti-PAF for 30 minutes and then triggered with PAF $10 \mu \mathrm{M}$ for 30 minutes (optimal dose and incubation time) for the degranulation assays. Rupatadine $(1 \mu \mathrm{M}$, $5 \mu \mathrm{M}$, and $10 \mu \mathrm{M})$, desloratadine $(1 \mu \mathrm{M}, 5 \mu \mathrm{M}$, and $10 \mu \mathrm{M})$, levocetirizine $(1 \mu \mathrm{M}, 5 \mu \mathrm{M}$, and $10 \mu \mathrm{M}), \mathrm{CV} 6209(0.2 \mu \mathrm{M}$ and $2 \mu \mathrm{M}), \mathrm{WEB} 2086(1 \mu \mathrm{M}, 10 \mu \mathrm{M}$, and $100 \mu \mathrm{M})$, and BN52021 $(1 \mu \mathrm{M}, 10 \mu \mathrm{M}$, and $100 \mu \mathrm{M})$ were tested. In order to evaluate the relationship between PAF-induced mast cell degranulation and calcium mobilization, several doses of PAF were tested $(1 \mu \mathrm{M}, 10 \mu \mathrm{M}$, and $50 \mu \mathrm{M})$ in LAD-2 calcium assays.

Mast cell degranulation was evaluated in hLMCs using histamine assays only. Mast cells were preincubated with antihistamines or anti-PAF for 30 minutes and then triggered with PAF $10 \mu \mathrm{M}$ for 30 minutes. Rupatadine, desloratadine, and levocetirizine were tested at $10 \mu \mathrm{M}$ because it was the only concentration that inhibited PAF-induced histamine release in LAD2. CV6209 was tested at $2 \mu \mathrm{M}$ and was the only anti-PAF antagonist used for these experiments owing to the lack of an inhibitory effect of BN52021 and WEB2086 in LAD-2 (data not shown).

PAF receptor expression was evaluated in mast cells from both LAD2 and hLMCs.

\section{Study Outcomes}

Trypan blue exclusion test of cell viability. The dye exclusion test was used to determine the number of viable cells after stimulation with PAF and antagonists (levocetirizine, rupatadine, desloratadine, CV6209, WEB2086, and BN52021) (all concentrations used in the experiments were tested). The technique is based on the principle that live cells possess intact cell membranes that exclude certain dyes, such as trypan blue, whereas dead cells do not [23].

$\beta$-hexosaminidase release assay. $\beta$-Hexosaminidase was quantified in the supernatant by release of 4-p-nitrophenol from p-nitrophenyl N-acetyl-beta-D-glucosaminide $(1.3 \mathrm{mg} / \mathrm{mL})$ in a sodium citrate buffer $(\mathrm{pH} 4.5)$. The reaction was stopped by addition of sodium carbonate buffer $0.2 \mathrm{M}(\mathrm{pH} 10.7)$. 4-P-nitrophenol release was quantified by absorbance at $405 \mathrm{~nm}$. The percentage of $\beta$-hexosaminidase release was calculated as follows: $\beta$-hexosaminidase release rate $(\%)=$ [sample release - spontaneous release/maximum release spontaneous release] $\times 100$.

Calcium mobilization. Calcium mobilization in LAD2 cells was followed by fluorometric analysis of free calcium with Fluo-4-AM fluorescent dye (Molecular Probes, Invitrogen). A total of $0.2 \times 10^{6}$ cells/point were loaded with $5 \mathrm{mM}$ Fluo-4-AM for 30 minutes at $4^{\circ} \mathrm{C}$ in the dark, washed twice with Tyrode buffer, and resuspended. Fluorometric measurements were made in a Modulus II Microplate Multimode Reader (Turner BioSystems), according to the manufacturer's instructions.

Enzyme-linked immunoabsorbent assay (ELISA) for histamine. Mast cell degranulation was also monitored by measuring the histamine released into the extracellular fluid. A commercial ELISA kit (Immunotech, Beckman Coulter Co) was used according to the manufacturer's instructions. The net percentage of histamine release was calculated from the ratio of each sample, with spontaneous release subtracted from total histamine.

$P A F$ receptor expression by Western blot. Total mast cell lysates from $1 \times 10^{6}$ cells for LAD2 and $0.5 \times 10^{6}$ cells for hLMCs were separated using SDS-PAGE (10\%) and electrotransferred onto polyvinylidene difluoride membranes (Millipore). The blot was tested with an antibody against the PAF receptor (Vitro). Blotted membranes were visualized using an enhanced chemiluminescence kit (Santa Cruz Biotechnology).

\section{Statistical Analysis}

Data are shown as a mean (SD). Groups were compared using a nonparametric test (Mann-Whitney with a HolmBonferroni correction). The $P$ value was adjusted depending on the number of comparisons (k). Therefore, a $P$ value $\leq .05 / \mathrm{k}$ was considered statistically significant.

\section{Results}

\section{Toxicity of PAF and Antagonists}

Only rupatadine and desloratadine $100 \mu \mathrm{M}$ induced a moderate increase in mast cell mortality compared with the diluent (DMSO 1\%) (data not shown). 
A

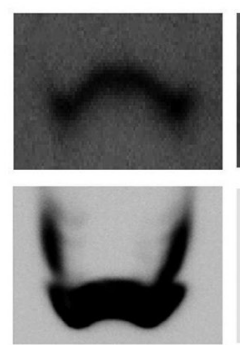

LAD2

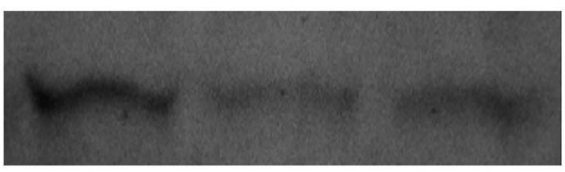

PAF receptor

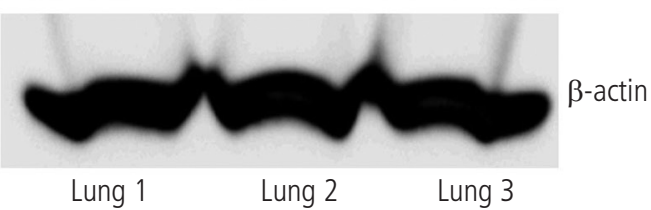

B

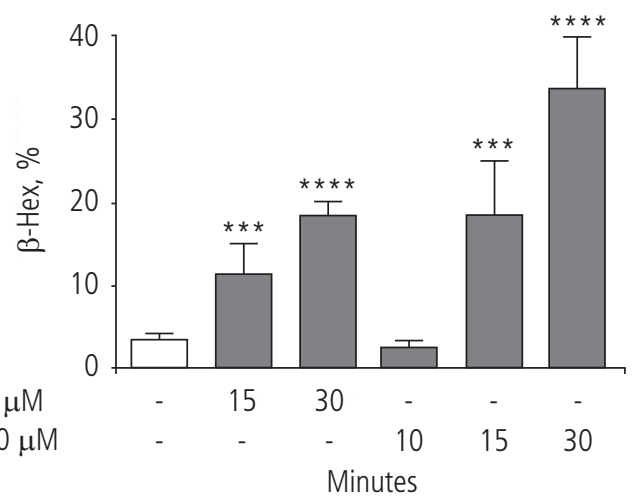

C

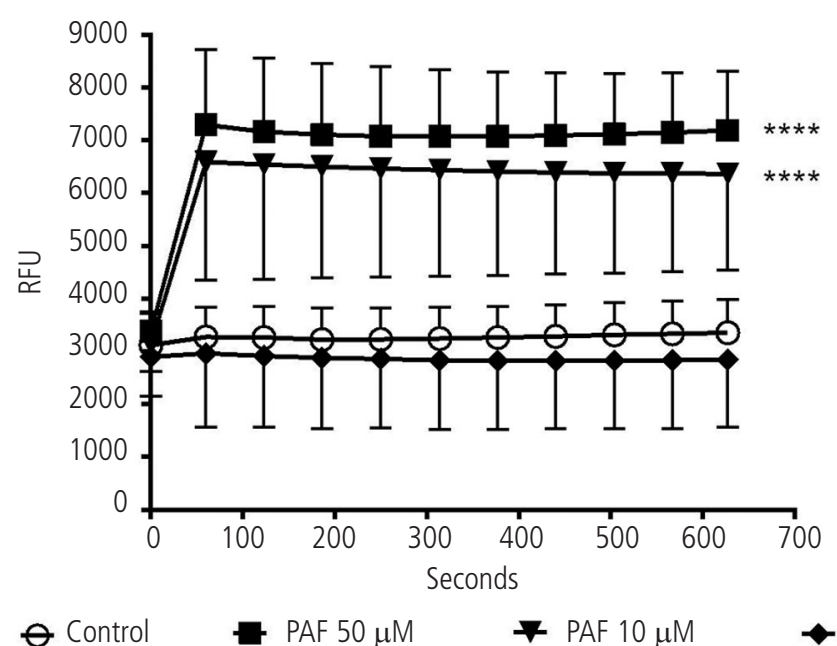

PAF $1 \mu \mathrm{M}$

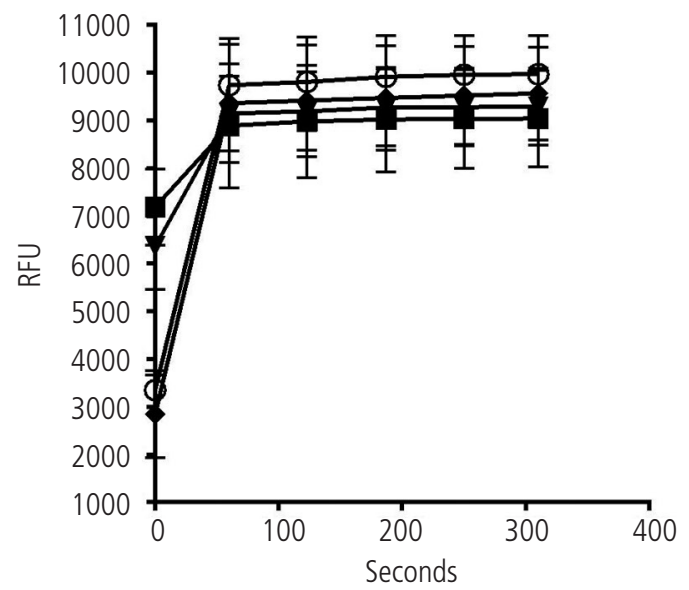

Figure 1. A, Expression of PAF receptor by Western blot in mast cells from both LAD2 (lane 1) and human lung ( $n=3$ ) (lanes 2-4). Effect of PAF on mast cell degranulation (LAD2). PAF time-course and dose response on (B) $\beta$-hexosaminidase release and (C) and calcium mobilization. Results are represented as mean (SD) of 3 independent experiments. ${ }^{* *} P<.001$ and ${ }^{* * * *} P<.0001$ compared with controls (no PAF). PAF indicates platelet-activating factor; $\beta$-hex (\%), $\beta$-hexosaminidase release rate; RFU, relative fluorescence units.

\section{PAF Receptor Expression}

PAF receptor expression (48-KDa band) was described in LAD2 for the first time and corroborated in hLMCs [5] (Figure 1A).

\section{PAF Time-Course and Dose-Response in LAD2 Activation}

PAF induced dose- and time-dependent cell activation in LAD2. Although PAF induced significant $\beta$-hexosaminidase release with both 1 and $10 \mu \mathrm{M}$ at both 15 and 30 minutes, we chose the concentration $(10 \mu \mathrm{M})$ and time (30 minutes) associated with the maximum release of mast cells $(33.5 \%)$ as the experimental positive control (Figure 1B).

\section{PAF-Induced Calcium Mobilization in LAD2}

A dose-dependent (10-50 $\mu \mathrm{M})$ PAF response was observed. Differences between $50 \mu \mathrm{M}$ and $10 \mu \mathrm{M}$ were not statistically significant. Neither PAF $1 \mu \mathrm{M}$ nor the negative control induced calcium influx (Figure 1C).

\section{Effect of PAF Antagonists on PAF-Induced Mast Cell Degranulation}

In LAD2, CV6209 inhibited PAF-induced $\beta$-hexosaminidase release at $0.2 \mu \mathrm{M}(45 \%, P<.01)$ and $2 \mu \mathrm{M}(56 \%, P<.001)$ (Figure 2A) and histamine release at $2 \mu \mathrm{M}(30 \%, P<.01)$ (Figure 2B). WEB2086 and BN52021 did not inhibit PAFinduced release of mast cells in LAD2 or in hLMCs (data not shown).

In hLMCs, CV6209 at $2 \mu \mathrm{M}$ inhibited PAF-induced histamine release $(24 \%, P<.01)$ (Figure $2 \mathrm{C}$ ).

Effect of Rupatadine, Levocetirizine, and Desloratadine on PAF-Induced Mast Cell Degranulation

$\beta$-hexosaminidase release in LAD2. Only rupatadine $10 \mu \mathrm{M}(48 \%)$ significantly $(P<.01)$ inhibited PAF-induced $\beta$-hexosaminidase release. No statistical differences were found with rupatadine $5 \mu \mathrm{M}(30 \%), 25 \mu \mathrm{M}(34 \%)$, or $100 \mu \mathrm{M}$ (no inhibition) or with levocetirizine from $1 \mu \mathrm{M}$ to $100 \mu \mathrm{M}$ (Figure $3 \mathrm{~A}$ and 3B, respectively). Desloratadine did not show any inhibitory effect at the concentrations tested (Figure 3C). 
A

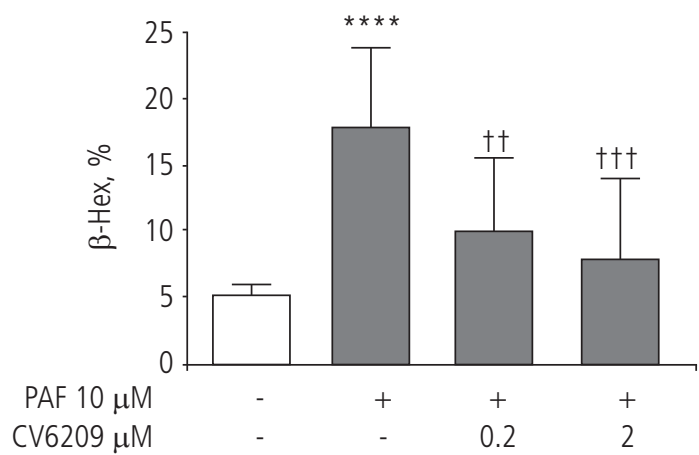

B

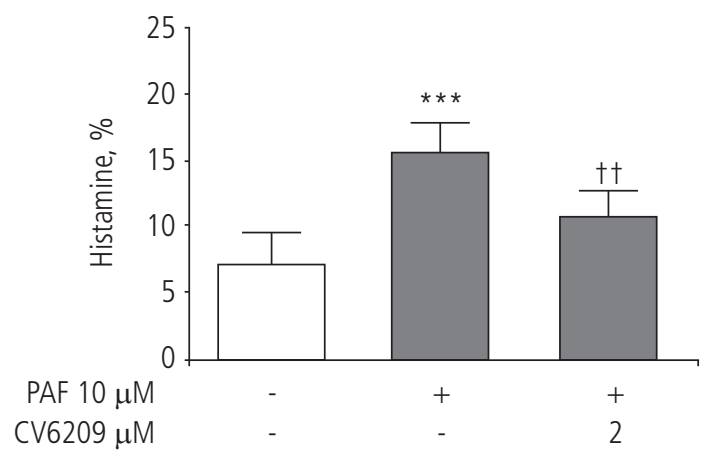

C

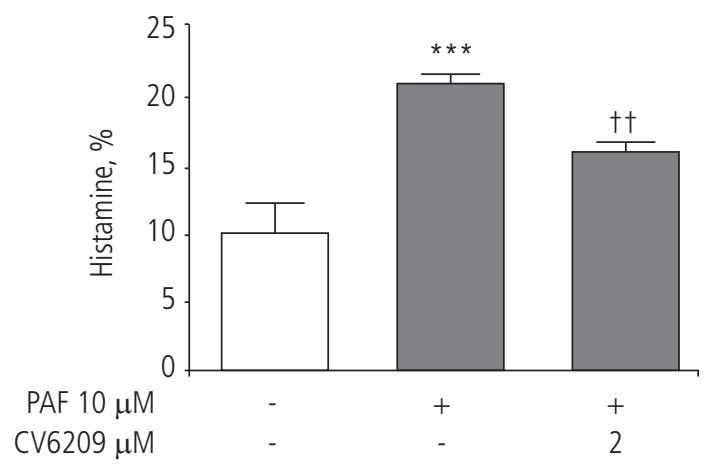

Figure 2. Effect of the specific anti-PAF receptor antagonist (CV6209) on PAF-induced mediator release from mast cells. Inhibitory effect on $\beta$-hexosaminidase $(A)$ and histamine release from the LAD2 cell line (B), and on histamine release from primary lung mast cells (C). Results are expressed as mean (SD) of 3 independent experiments. ${ }^{* * * *} P<.0001$ and ${ }^{*}{ }^{*} P<.001$ compared with controls (no PAF); $\uparrow \uparrow \uparrow P<.001$ and $\dagger+P<.01$ compared with PAF. PAF indicates platelet-activating factor; $\beta$-hex (\%), $\beta$-hexosaminidase release rate; histamine (\%), histamine release rate.

Histamine release in LAD2. Rupatadine $5 \mu \mathrm{M}(29 \%)$ and $10 \mu \mathrm{M}(30 \%)$ and levocetirizine $5 \mu \mathrm{M}(25 \%), 10 \mu \mathrm{M}$ $(27 \%)$, and $25 \mu \mathrm{M}(25 \%)$ significantly inhibited PAF-induced histamine release $(P<.01)$ (Figure $4 \mathrm{~A}$ and $4 \mathrm{~B})$. Desloratadine did not significantly inhibit histamine release at any of the concentrations tested (Figure 4C).

Histamine release in hLMCs. Rupatadine $10 \mu \mathrm{M}(12 \%)$ significantly $(P<.01)$ inhibited PAF-induced histamine release, but this effect was not observed with either desloratadine $(2 \%)$ or levocetirizine (4\%) (Figure 5).
A

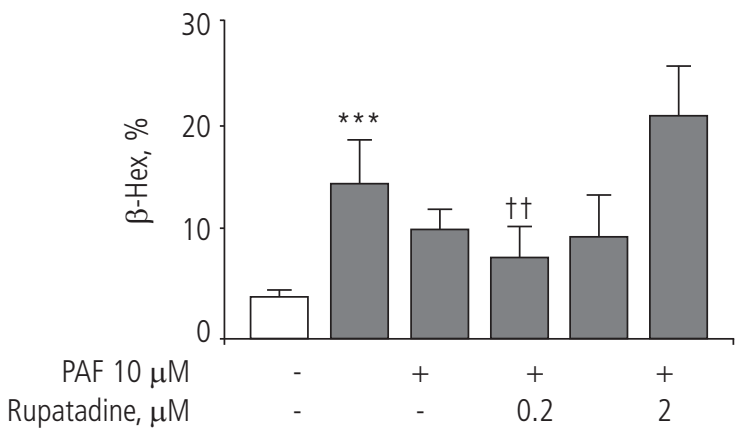

B

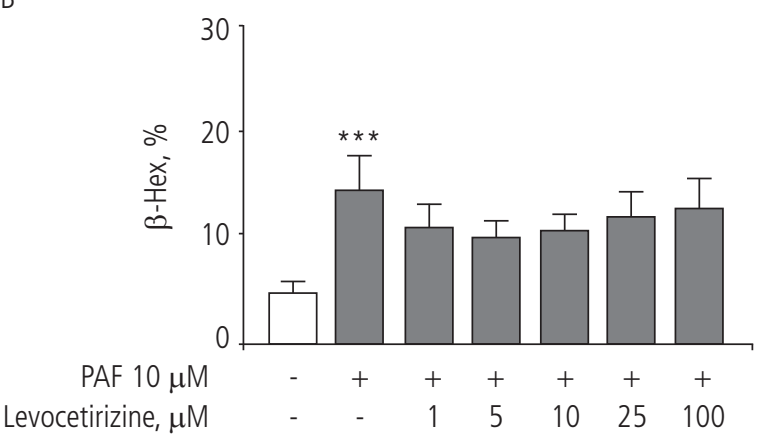

C

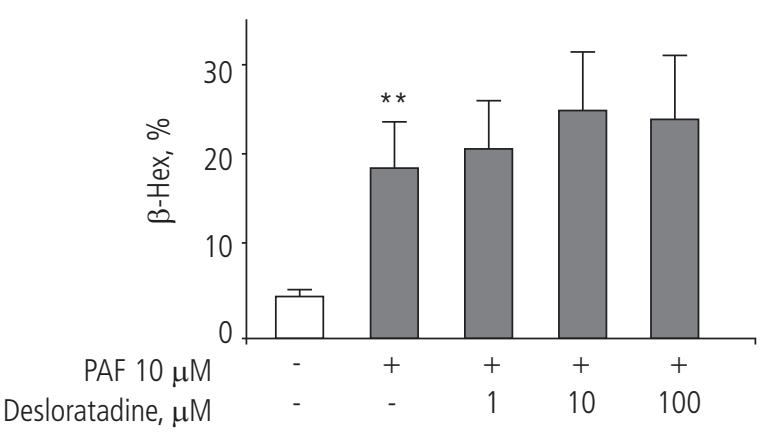

Figure 3. Effect of second-generation antihistamines on PAF-induced $\beta$-hexosaminidase release in the LAD2 cell line. Rupatadine $(A)$ and to lesser extent levocetirizine (B), but not desloratadine (C) inhibit $\beta$-hexosaminidase release. Results are expressed as mean (SD) of 3 independent experiments. ${ }^{* *}{ }^{*} P<.001$ and ${ }^{* *} P<.01$ compared with controls; $\uparrow \uparrow P<.01$ compared to PAF. PAF indicates platelet-activating factor; $\beta$-hex (\%), $\beta$-hexosaminidase release rate.

\section{Discussion}

LAD2 is one of 3 well-established human mast cell lines and usually serves as a replacement for mast cells in mature tissue [24]. PAF receptor expression has been demonstrated in several cell types, including platelets, eosinophils, and hLMCs [25-27], but never in LAD2. In our study, we demonstrated for the first time the presence of the PAF receptor in $\mathrm{LAD} 2$. We also confirmed that the PAF receptor is present in hLMCs [5]. 
A

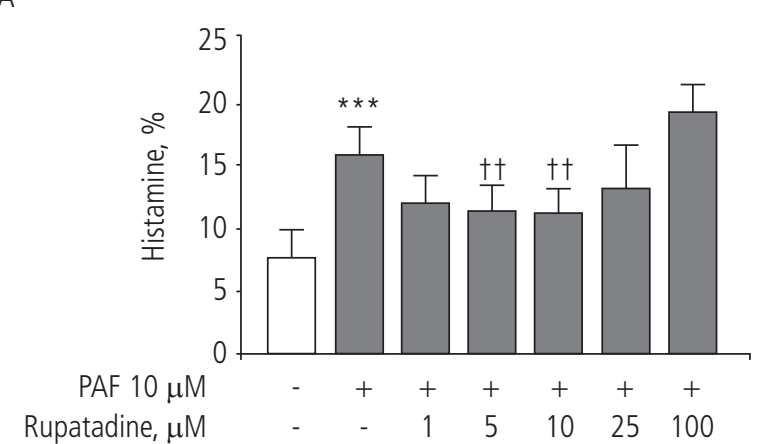

B

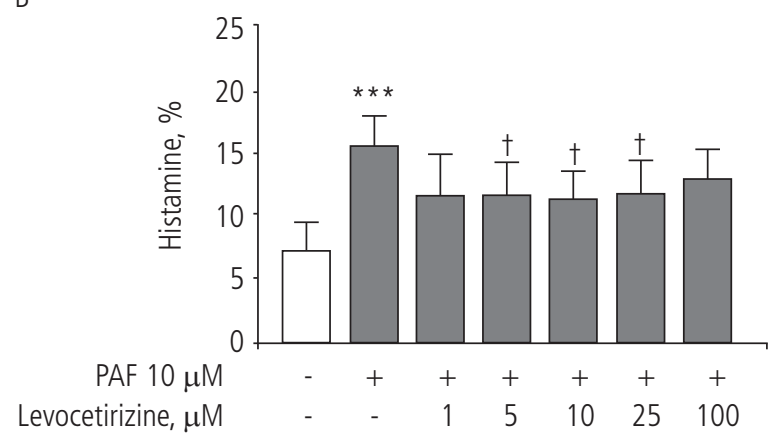

C

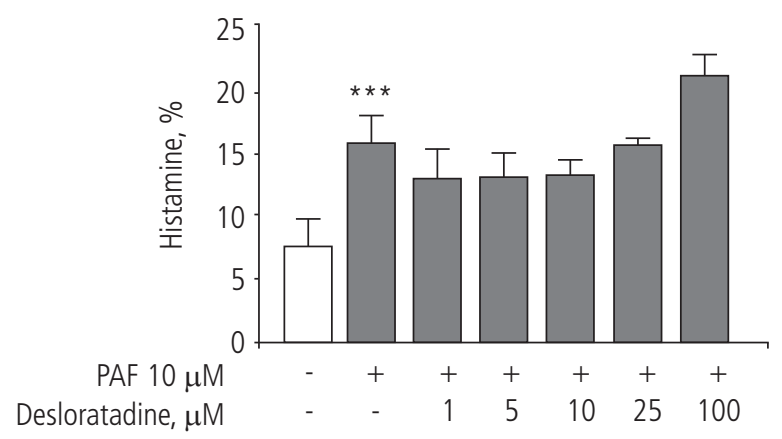

Figure 4. Effect of second-generation antihistamines on PAF-induced histamine release in the LAD2 cell line. Rupatadine $(A)$ and levocetirizine (B), and to a lesser extent desloratadine (C), inhibit histamine release. The results are expressed as mean (SD) of 3 independent experiments. ${ }^{* *} P<.001$ compared with controls. $+\uparrow P<.01$ and $+P<.05$ compared with PAF. PAF indicates platelet-activating factor; Histamine (\%), histamine release rate.

In the MASPAF study, we demonstrated that rupatadine and, to a lesser extent, levocetirizine inhibited PAF-induced human mast cell degranulation and suggest that this effect could be mediated through the PAF receptor. Desloratadine, an antihistamine with no anti-PAF effect, failed to show any consistent inhibitory effect.

In addition to mast cell degranulation, our study also confirmed the ability of PAF to mobilize intracellular calcium, as previously demonstrated by other authors $[5,13]$. This evidence and the inhibitory effect demonstrated by PAFspecific antagonists such as CV6209 suggest that the PAF effect in our model may be mediated by PAF receptor activation.

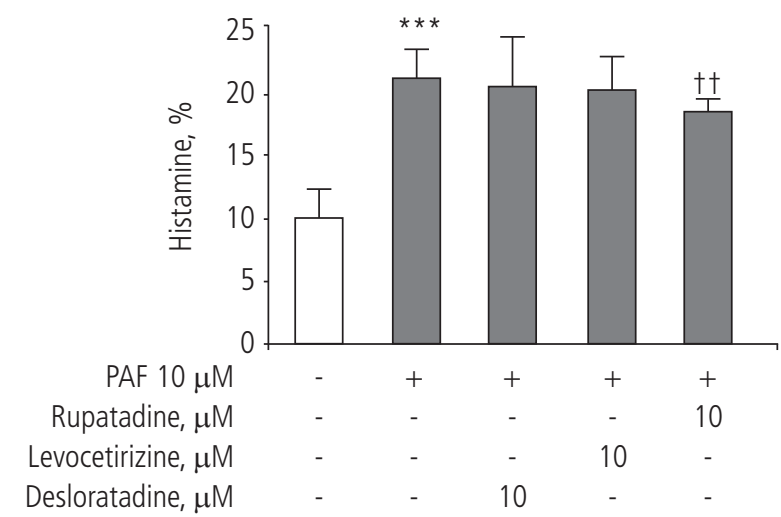

Figure 5. Effect of second-generation antihistamines on PAF-induced histamine release in primary human lung mast cells. Rupatadine, but not levocetirizine or desloratadine, inhibits histamine release. Results are expressed as mean (SD) of 3 independent experiments. ${ }^{* *}{ }^{*} P<.001$ compared with controls. $\uparrow+P<.01$ compared with PAF. PAF indicates platelet-activating factor; Histamine (\%), histamine release rate.

Kajiwara et al [5] recently demonstrated the activation of human mast cells through the PAF receptor, reaching 20\%$30 \%$ of total histamine release in hLMCs at a concentration as low as $1 \mathrm{nM}$ [5]. The concentration used in our study was higher $(10 \mu \mathrm{M})$ than that used in the study by Kajiwara et al, probably owing to differences in the cell types used (LAD2 and hLMCs vs mast cells from peripheral blood-derived progenitors) and the high interindividual sensitivity in response to PAF stimulation observed in hLMCs. Our findings differ from those of Alevizos et al [19], who used LAD2 stimulated with PAF. Although histamine release was induced with a PAF concentration as low as $0.01 \mu \mathrm{M}, \beta$-hexosaminidase release could not be induced at that dose. In our study, PAF $10 \mu \mathrm{M}$ induced both histamine and $\beta$-hexosaminidase release with no impact on cell viability. Moreover, we were unable to demonstrate mobilization of calcium with PAF concentrations below $10 \mu \mathrm{M}$, suggesting that lower concentrations of PAF would not activate the PAF receptor in LAD2.

In our study, CV6209 inhibited PAF-induced histamine and $\beta$-hexosaminidase release in both LAD2 and hLMCs. However, the PAF antagonists BN52021 and WEB2086 had no inhibitory effect (data not shown). Although several studies have compared rupatadine with WEB2086 and BN52021 and demonstrated a greater effect of these PAF antagonists on PAFinduced mortality in mice or platelet aggregation in rabbits and human samples [18], their effect on mast cells has never been evaluated. On the other hand, it has been demonstrated that CV6209 inhibits PAF-induced histamine release in human peripheral blood-derived mast cells, although it has never been compared with rupatadine [5]. Our results showed that the inhibitory effect of rupatadine was comparable to that of CV6209 on LAD2, although the effect of CV6209 on hLMCs was greater than that of rupatadine.

In the present study, we demonstrated that rupatadine consistently inhibited PAF-induced degranulation, blocking histamine and $\beta$-hexosaminidase release in both LAD2 and hLMCs. 
In one of the few studies investigating the role of rupatadine in mast cells, Alevizos et al [19] compared the effect of rupatadine and diphenhydramine on PAF-induced histamine and cytokine release in LAD2. The discrepancies in the effect of rupatadine observed in our study and that of Alevizos et al could be related to differences in the PAF concentrations used. We used a significantly higher dose of PAF $(10 \mu \mathrm{M})$ as a degranulation trigger and found that rupatadine was capable of inhibiting PAF-induced degranulation in a range that runs from $1 \mu \mathrm{M}$ to $10 \mu \mathrm{M}$. Surprisingly, despite using a 10-fold lower concentration of PAF, Alvezios et al showed that only rupatadine at $25 \mu \mathrm{M}$ had a significant inhibitory effect. Furthermore, both $\mathrm{H} 1$ receptor antagonists - diphenhydramine in the study by Alvezios et al and desloratadine in ours-had no inhibitory effect on PAF-induced histamine or cytokine production, suggesting a lack of anti-PAF effect. Other previous studies performed with rupatadine in human mast cells, specifically in cord blood mast cells, have shown that rupatadine $25 \mu \mathrm{M}$ inhibited IgE-mediated release of TNF- $\alpha$ and cytokines (IL-6, IL-8, IL-10, and IL-13) [17]. In HMC-1 and LAD2, rupatadine $10 \mu \mathrm{M}$ to $50 \mu \mathrm{M}$ inhibited cytokine release induced by substance $\mathrm{P}$, with no impact on cell viability at any concentration [17].

The present study also showed that desloratadine had no inhibitory effect and that levocetirizine inhibited PAFinduced degranulation of LAD2 at some concentrations but not in hLMCs. However, Weller et al [28] demonstrated that desloratadine $1 \mu \mathrm{M}$ was able to inhibit histamine release in isolated human skin mast cells. Queralt et al [29] reported a similar effect for loratadine and rupatadine in canine mast cells and HMC-1 after stimulation with the calcium ionophore A23187, Con A, and anti-IgE. However, in our study, desloratadine, a metabolite of loratadine, showed no inhibitory effect during stimulation with PAF in LAD2 and hLMCs. The different mast cell phenotype observed in human skin and human lung [30,31], as well as the different trigger used (antiIgE, calcium ionophore, Con A, and substance P) [28], could account for this discrepancy [32]. Although desloratadine, a second-generation antihistamine, has been shown to have some antiallergic effects [33] and to be up to 10 times more potent than loratadine in antagonizing histamine-induced increases in nasal microvascular permeability [34], in the light of our findings it lacks an anti-PAF effect.

To our knowledge, no studies have examined levocetirizine in mast cells. As a second-generation antihistamine, some antiallergic effects have been reported [35], although none of them are related to PAF. However, albeit to a lesser extent than rupatadine, levocetirizine inhibited PAF-mediated LAD2 degranulation (mainly histamine release at several concentrations), a finding that also suggests potential anti-PAF activity in LAD2 but not in primary hLMCs.

Of note, the concentration of antihistamine necessary to decrease mast cell activation in vitro in our study may be higher than that necessary in vivo. Single cell models are partially representative of what is happening in a whole organism (a human being), and the role of metabolic pathways present in the in vivo model is neglected in in vitro (cell-based) studies. Furthermore, the cell culture environment does not exactly reproduce in vivo conditions. Therefore, our study must be considered an in vitro model for investigation of the effect of the drug on mast cell activation/mediator release, although the concentrations used are not useful as a reference for doses in treatment (an in vivo dose search is always mandatory).

Finally, the strongest inhibitory effect of rupatadine in PAFinduced mast cell degranulation from both LAD2 and hLMCs clearly correlates with its clinical effect in allergic rhinitis [10], where rupatadine, but not levocetirizine, showed an inhibitory effect (reduced total nasal symptoms score).

In conclusion, we demonstrated that rupatadine andalbeit to a lesser extent - levocetirizine have anti-PAF activity in human mast cells. The dual antihistamine and anti-PAF activity of rupatadine may provide the drug with greater antiinflammatory/antiallergic activity, as reported elsewhere [10].

\section{Acknowledgments}

We thank Maria Perez for technical support.

\section{Funding}

This study was supported by a Sociedad Española de Alergia e Immunología Clínica (SEAIC) grant, Ministerio de Economia y Competitividad-Carlos III Health Institute (FISPI09/1202), Spain and Grupo Uriach SA, Barcelona, Spain. RM-C was the recipient of the "Rio Hortega" Fellowship, Ministerio de Economia y Competitividad, Carlos III Health Institute, Spain.

\section{Conflicts of Interest}

$\mathrm{JM}$ is or has been a member of national and international scientific advisory boards (consulting) and has received fees for lectures and grants for research projects from ALKAbelló, Boheringer-Ingelheim, Crucell, Esteve, FAES, GSK, Hartington Pharmaceuticals, Johnson \& Johnson, MEDA Pharma, MSD, Novartis, Pierre Fabre, Sanofi-Aventis, Schering Plough, UCB, and Uriach Group. AV is or has been member of national scientific advisory Boards (consulting), received fees for lectures and grants for research projects from Boheringer-Ingelheim, Esteve, FAES, GSK, Chiesi, MEDA Pharma, MSD, Novartis, Leti, Stallergenes, Sanofi-Aventis, Orion Pharma, Vifor, UCB, and Uriach Group. CP has been or is a member of national and international scientific advisory boards (consulting) and has received lecture fees and grants for research projects from Esteve, FAES, MSD, Novartis, Chiesi, Grupo Uriach, and GSK. JB is or has been a member of national scientific advisory boards (consulting) and received fees for lectures from FAES, UCB, Grupo Uriach and Hall Allergy. RM-C, EA-E, IT-A, MM, and JS declare that they have no conflicts of interest.

\section{Previous Presentations}

This study was presented in part as a poster at the Annual Meeting of the American Academy of Asthma, Allergy and Immunology (AAAAI) in New Orleans, United States of America, February 2012.

\section{References}

1. Spina D, Coyle AJ, Page CP. The role of platelet activating factor in allergic inflammation. Pulm Pharmacol. 1989;2:13-9. 
2. Kuitert LM, Angus RM, Barnes NC, Barnes PJ, Bone MF, Chung KF, Fairfax AJ, Higenbotham TW, O'Connor BJ, Piotrowska B. Effect of a Novel Potent Platelet-activating Factor Antagonist Modipafant, in Clinical Asthma. Am J Respir Crit Care Med. 1995:151:1331-5.

3. Mullol J, Bousquet J, Bachert C, Canonica WG, GimenezArnau A, Kowalski ML, Martí-Guadaño E, Maurer M, Picado C, Scadding G, Van Cauwenberge P. Rupatadine in allergic rhinitis and chronic urticaria. Allergy. 2008;63 Suppl 87:5-28.

4. Vadas P1, Gold M, Perelman B, Liss GM, Lack G, Blyth T, Simons FE, Simons KJ, Cass D, Yeung J. Platelet-activating factor, PAF acetylhydrolase, and severe anaphylaxis. N Engl J Med. 2008:358:28-35.

5. Kajiwara N, Sasaki T, Bradding P, Cruse G, Sagara H, Ohmori K, Saito H, Ra C, Okayama Y. Activation of human mast cells through the platelet-activating factor receptor. J Allergy Clin Immunol. 2010;125:1137-45.

6. Kuitert L, Barnes N. PAF and asthma--time for an appraisal? Clin Exp Allergy. 1995; 12:1159-62.

7. Chan-Yeung M, Lam S, Chan H, Tse KS, Salari H. The release of platelet-activating factor into plasma during allergen-induced bronchoconstriction. J. Allergy Clin Immunol. 1991;87:66773.

8. Mullol J, Bousquet J, Bachert C, Canonica GW, Giménez-Arnau A, Kowalski ML, Simons FE, Maurer M, Ryan D, Scadding $\mathrm{G}$. Update on rupatadine in the management of allergic disorders. Allergy. 2015;70 Suppl 100:1-24.

9. Muñoz-Cano R, Valero A, Roca-Ferrer J, Bartra J, SanchezLopez J, Mullol J, Picado C. Platelet-activating factor nasal challenge induces nasal congestion and reduces nasal volume in both healthy volunteers and allergic rhinitis patients. Am J Rhinol Allergy. 2013;27:48-52.

10. Muñoz-Cano R, Valero A, Izquierdo I, Sanchez-Lopez J, Domenech A, Bartra J, Mullol J, Picado C. Evaluation of nasal symptoms induced by platelet activating factor, after nasal challenge in both healthy and allergic rhinitis subjects pretreated with rupatadine, levocetirizine or placebo in a crossover design. Allergy Asthma Clin Immunol. 2013;9(1):43.

11. Alfaro V. Role of histamine and platelet-activating factor in allergic rhinitis. J. Physiol. Biochem. 2004;60:101-11.

12. Gill $P$, Jindal NL, Jagdis A VP. Platelets in the immune response: Revisiting platelet-activating factor in anaphylaxis. J Allergy Clin Immunol. 2015:135:1424-32.

13. Nilsson G, Metcalfe DD, Taub DD. Demonstration that plateletactivating factor is capable of activating mast cells and inducing a chemotactic response. Immunology. 2000;99:314-9.

14. Spence DP, Johnston SL, Calverley PM, Dhillon P, Higgins C, Ramhamadany E, Turner S, Winning A, Winter J, Holgate ST.. The effect of the orally active platelet-activating factor antagonist WEB 2086 in the treatment of asthma. Am J Respir Crit Care Med. 1994;149:1142-8.

15. Martínez-Cócera C1, De Molina M, Martí-Guadaño E, Pola J, Conde J, Borja J, Pérez I, Arnaiz E, Izquierdo I; Spanish Rupatadine Rhinitis Study Group. Rupatadine $10 \mathrm{mg}$ and cetirizine $10 \mathrm{mg}$ seasonal allergic rhinitis: A randomised, double-blind parallel study. J Investig Allergol Clin Immunol. 2005;15:22-9.

16. Dubertret L1, Zalupca L, Cristodoulo T, Benea V, Medina I, Fantin S, Lahfa M, Pérez I, Izquierdo I, Arnaiz E. Once-daily rupatadine improves the symptoms of chronic idiopathic urticaria: a randomised, double-blind, placebo-controlled study. Eur J Dermatol. 2007;17:223-8.

17. Vasiadi M1, Kalogeromitros D, Kempuraj D, Clemons A, Zhang B, Chliva C, Makris M, Wolfberg A, House M, Theoharides TC. Rupatadine inhibits proinflammatory mediator secretion from human mast cells triggered by different stimuli. Int Arch Allergy Immunol. 2009;151:38-45.

18. Merlos M1, Giral M, Balsa D, Ferrando R, Queralt M, Puigdemont A, García-Rafanell J, Forn J.. Rupatadine, a new potent, orally active dual antagonist of histamine and platelet-activating factor (PAF). J Pharmacol ExpTher. 1997;280:114-21.

19. Alevizos M1, Karagkouni A, Vasiadi M, Sismanopoulos N, Makris M, Kalogeromitros D, Theoharides TC. Rupatadine inhibits inflammatory mediator release from human laboratory of allergic diseases 2 cultured mast cells stimulated by platelet-activating factor. Ann Allergy Asthma Immunol. 2013;111:542-7.

20. Kulka M, Metcalfe DD. Isolation of tissue mast cells. Curr Protoc Immunol 2010; Chapter 7:Unit 7.25.

21. Dupre DJ, Le Gouill C, Rola-Pleszczynski M, Stankova J. Inverse agonist activity of selected ligands of platelet-activating factor receptor. J Pharmacol Exp Ther. 2001;299:358-65.

22. Northover AM, Northover BJ. Inhibition of NO-synthase and degranulation of rat omental mast cells in vitro. Mediators Inflamm. 1996;5:257-61.

23. Strober W. Trypan blue exclusion test of cell viability. Curr Protoc Immunol 2001; Appendix 3: Appendix 3B.

24. Guhl S, Babina M, Neou A, Zuberbier T, Artuc M. Mast cell lines HMC-1 and LAD2 in comparison with mature human skin mast cells--drastically reduced levels of tryptase and chymase in mast cell lines. Exp Dermatol. 2010;19:845-7.

25. Ishii S, Nagase T, Shimizu T. Platelet-activating factor receptor. Prostaglandins Other Lipid Mediat. 2002;68-69:599-609.

26. Kato M, Kita H, Tachibana A, Hayashi Y, Tsuchida Y, Kimura $H$. Dual signaling and effector pathways mediate human eosinophil activation by platelet-activating factor. Int Arch Allergy Immunol. 2004;Supl 1:37-43.

27. Shirasaki H1, Seki N, Kikuchi M, Kanaizumi E, Watanabe K, Konno N, Himi T.. Expression and localization of plateletactivating factor receptor in human nasal mucosa. Ann Allergy Asthma Immunol. 2005;95:190-6.

28. Weller K, Maurer M. Desloratadine inhibits human skin mast cell activation and histamine release. J Invest Dermatol. 2009;11:2723-6.

29. Queralt M, Brazis P, Merlos M, de Mora F, Puigdemont A. In vitro inhibitory effect of rupatadine on histamine and TNFalpha release from dispersed canine skin mast cells and the human mast cell line HMC-1. Inflamm Res. 2000;49:355-60.

30. Irani AA, Schechter NM, Craig SS, DeBlois G, Schwartz LB. Two types of human mast cells that have distinct neutral protease compositions. Proc Natl Acad Sci USA. 1986;83:4464-8.

31. Lowman MA, Rees PH, Benyon RC, Church MK. Human mast cell heterogeneity: histamine release from mast cells dispersed from skin, lung, adenoids, tonsils, and colon in response to IgE-dependent and nonimmunologic stimuli. J Allergy Clin Immunol. 1988;81:590-7.

32. He SH, He YS, Xie H. Activation of human colon mast cells through proteinase activated receptor-2. World JGastroenterol. 2004; 10:327-31. 
33. Agrawal DK. Anti-inflammatory properties of desloratadine Clin Exp Allergy 2004;34(9):1342-8.

34. Kreutner W, Hey JA, Anthes J, Barnett A, Young S, Tozzi S. Preclinical pharmacology of desloratadine, a selective and nonsedating histamine $\mathrm{H} 1$ receptor antagonist. 1st communication: receptor selectivity, antihistaminic activity, and antiallergenic effects. Arzneimittelforschung. 2000;50:345-52.

35. Walsh GM. The anti-inflammatory effects of levocetirizine--are they clinically relevant or just an interesting additional effect? Allergy Asthma Clin Immunol. 2009;5:14.
I Manuscript received February 11, 2016; accepted for publication October 7, 2016.

\section{Rosa Muñoz-Cano}

Unitat d'Al·lèrgia. Servei de Pneumologia

i Al·lèrgia Respiratòria

Hospital Clínic, IDIBAPS

Villarroel 170

Barcelona 08036

Catalonia, Spain

E-mail: rmunoz@clinic.ub.es 